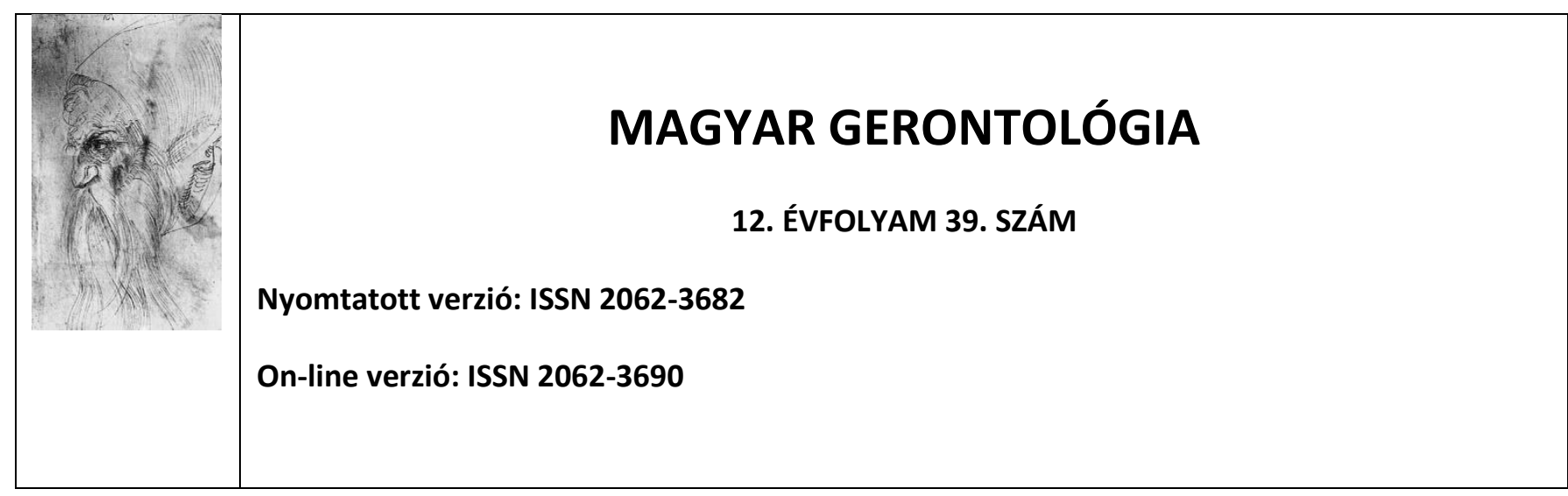

\title{
AKTÍV, ALKOTÓ IDŐSÖDÉS I. - MEGKÜZDÉS
}

\author{
Ferwagner Anna \\ ferwagner.anna@gmail.com \\ Pék Győző \\ Debreceni Egyetem, Pszichológiai Intézet \\ 4032 Debrecen, Egyetem tér 1. \\ viktorbaker55@gmail.com
}

\begin{abstract}
ÖSSZEFOGLALÁS
Háttér és célkitüzések: Kutatásunkban azt vizsgáltuk, hogy életük utolsó szakaszát hogyan élik meg azok az idős emberek, akik életük ezen szakaszában maradandó alkotás létrehozására irányuló alkotó (kézműves, képzőművész, textilművész) tevékenységgel foglalkoznak. Módszer: Vizsgálatunkban a proaktív megküzdést, az élettel való elégedettséget, az időskori depressziót és az élet értelmét vizsgáló kérdőíveket alkalmaztunk. Eredmények és következtetések: Az értelem keresésének alkotóknál mért magasabb szintje összefüggésben lehet a keresés összetett jellegével, amely magában hordozhatja az életszakaszváltással együtt járó lelki feszültséget és az azzal való megküzdést és a fejlődés lehetőségét is, így az alkotó tevékenység egyfajta védőfaktorként értelmezhető. Az alkotók csoportjában a reflektív megküzdés (többféle megoldási lehetőség és a megoldáshoz szükséges erőforrások feltárása és elemzése) mutatta a legmagasabb értéket, ami az alkotó tevékenységet folytatók kreativitásából és divergens gondolkodásából adódhat.
\end{abstract}

Kulcsszavak: időskorúak, proaktív megküzdés, élettel való elégedettség, depresszió, élet értelme 


\title{
ACTIVE, CREATIVE AGING I. - COPING
}

\begin{abstract}
SUMMARY
Background and aims: In our research, we examined how the last stage of their lives is experienced by older people who engage in creative activity (handicraft, fine arts, textile art) aimed at creating a lasting work at this stage of their life. Methods: In our study, we used questionnaires examining proactive coping, life satisfaction, geriatric depression, and the meaning of life. Results and discussion: The higher level of search for meaning measured by creators may be related to the complex nature of the search, which may involve the mental stress associated with life cycle change and the ability to cope with it and the possibility of development, so that creative activity can be interpreted as a kind of protective factor. In the group of creators, reflective coping (exploring and analyzing several solution options and the resources needed for the solution) showed the highest value, which may result from the creativity and divergent thinking of those engaged in creative activity.
\end{abstract}

Keywords: elderly, proactive coping, life satisfaction, depression, meaning of life

\section{BEVEZETÉS}

Az elmúlt évtizedek népességstatisztikai adatai egyértelmüen bizonyítják, hogy folyamatosan nő a születéskor várható élettartam és a népességen belül egyre nagyobb az idősek aránya. A World Population Ageing 2013 adatai szerint a 60 év felettiek aránya 2013-ban világszerte 11,7 \% volt, s a prognózis szerint 2050-re ez az arány világviszonylatban is eléri a 21,1\%-ot. A 80 év felettiek aránya az idősek közt rohamosan nő, a 2013. évi 14 \%-hoz képest 2050-re 19 \%-ra nőhet.

A 65 évesnél idősebb magyar népesség aránya 1990-ben $13 \%$ volt, 2017-ben $19 \%$-ra növekedett és az előrejelzések szerint 2070-re a 29 \%-ot is elérheti. (Monostori és Gresits, 2018) Megváltozott az idősek korösszetétele is, hiszen 2000-ben a népesség 17,6 \%-a volt 60-80 év közötti és 2,5\%-a 80 év feletti, 2016-ban azonban a 60-80 év közötti népesség aránya 21,4 \%-ra, a 80 év felettiek aránya pedig 4,3 \%-ra nőtt. (Bácskay és mts., 2017, 1.2-1.3. táblázat alapján)

Míg 1990-ben a születéskor várható átlagos élettartam férfiak esetében 65,1 év, nők esetében 73,7 év volt, addig 2016-ban férfiak esetében már 72,4 év, nők esetében 79,2 év. A várható élettartam tehát nők esetében lényegesen magasabb, mint a férfiaknál, így az idősebb korosztály „elnőiesedése” is megfigyelhető. A férfiak és nők arányát tekintve 2000-ben népesség 16,3\%-a volt 60 év feletti 
férfi és 23,6 \%-a nő, míg 2016-ban a népesség 21,4 \%-a volt 60 év feletti férfi és 29,5\% \%-a nő. (Bácskay és mts., 2017, 1.3. táblázat alapján)

\section{Idősödés és az idöskor krizisei}

Az egyes életszakaszokba történő átmenet, az életszakaszváltás, így az idősödés kezdete és időszaka, egyben krízisnek is tekinthető, hiszen jelentős biológiai, pszichológiai, társadalmi változások mennek végbe és az új életszakasz újfajta kihívásokat tartogat, újfajta képességeket igényel, az ehhez rendelkezésre álló megküzdési stratégiák azonban már nem elégségesek (Füzesi, Törőcsik és Lampek, 2013; Hajduska, 2015).

Ebben az életszakaszban az általános egészségi állapot már alapvetően romlásnak indul, az életminőséget rontó krónikus betegségek jelenhetnek meg. Romlik az érzékszervi, mozgásrendszeri, szív- és érrendszeri, légzőszervrendszeri müködés hatékonysága. A kognitív funkciók, az észlelés, emlékezés, tanulás hatékonyságának fokozatos csökkenése is megkezdődik (Balaskó, Pétervári és Székely, 2013).

A családi kapcsolatok terén is jelentős változások zajlanak. Egyrészt előfordulhat, hogy a gyermekek még nem hagyták el a családi otthont, még tanulmányokat folytatnak, vagy munkába állásuk elején tartanak, ezáltal az idősödő szülők anyagi támogatására szorulnak. Másrészt előfordulhat - s talán ez a gyakoribb jelenség -, hogy már unokáik vannak, akik nevelésében tevékenyen szükséges részt venniük. Harmadrészt az idősödő korosztály képviselőinek szülei is élhetnek még, így segítésük, gondozásuk szintén ezen korosztályt köti le. Fentiek bármelyike, de főként halmozódásuk rendkívüli terhet róhat az ebben a korban egyébként is jelentős biológiai és kognitív változáson keresztülmenő emberekre. Ezen időszakban rendkívül fontos a családi integritás, a generációk közötti kiegyensúlyozott kapcsolat, amely kifejezetten erősíti az önértékelést, javítja az életminőséget és csökkenti a depresszió valószínűségét. Nehezebb helyzetben vannak azok, akik épp ekkor maradnak egyedül társuk elvesztését követően (Kopp és Székely, 2013).

Szintén az időskorba történő átmenet és az időskor elejének idejére tehető a munkaerőpiacról való kikerülés, a nyugdíjba vonulás, amely sok esetben az idő strukturálatlanságát, az improduktivitás megélését, a motiváció és aktivitás csökkenését és a társas kapcsolatok megfogyatkozását vonja maga után (Hajduska, 2015).

A korábbi célok ellehetetlenülése, feladása a sikertelenség érzéséhez, az önbecsülés csökkenéséhez, depresszióhoz vezethet. Érdemes hát a céloknak az aktuális élethelyzethez viszonyítása és szükség szerinti módosítása, az aktuális élethelyzethez, erőforrásokhoz igazítása. A célok átformálása általában akkor válik szükségessé, mikor életfordulós változás következik be (pl. 
házasságkötés, gyermekvállalás, nyugdíjba vonulás) vagy ha egy adott életszakasszal nem tud megbirkózni, így az adott életszakasz sikeres lezárásához szintén a célok módosítása szükséges (Brandtstadter, 2011; Nurmi és Salmela-Aro, 2011).

Az életminőség mutatók életkor szerinti megoszlása alapján a reménytelenség, depresszió, unalom és vitális kimerültség a 65 év felettiek esetében a legmagasabb. Az országos átlag alapján enyhe depresszió mutatható ki, míg a jóllét és kompetencia érzése ebben a korosztályban a legalacsonyabb (Kopp és Kovács, 2006). Az idősödés krízisére az emberek visszahúzódással, izolálódással, depresszióval, beszüküléssel, halmozódó megbetegedésekkel, az aktivitás görcsös bizonyításával válaszolhatnak, ugyanakkor kreatív szerepmegoldások is adódhatnak, mint például a részmunka vagy önkéntes munka lehetősége, az alkotó, kreatív hobbik vagy az aktív nagyszülőszerep (Hajduska, 2015).

Megküzdés

Életünk során meg kell birkóznunk a mindennapok kihívásaival, követelményeivel, a változásokkal és az önmagunk számára kitüzött célokkal. A változásokkal való megküzdés, a nehézségek kezelése és az új követelményekhez való alkalmazkodás, új képességek kifejlesztését teheti szükségessé.

A klasszikus analitikus felfogás szerint a megküzdés azon tudatos ego-manőverek összessége, amelyekkel az ego a külvilágból jövő fenyegetéseket kezeli, szemben a tudattalanul működő elhárító mechanizmusokkal, amelyek a belső veszélyek ellen védik az egot. A trait-modell szerint a megküzdés módja stabil személyiségvonásnak tekinthető, az emberek konzisztens védekező mechanizmusokat dolgoznak ki a fenyegetések elhárítására és következetesen alkalmazzák stressz esetén. Az eredményes megküzdés legfőbb személyiségfaktorainak a kontrollgyakorlás képessége, a tanult leleményesség, a lelkileg edzett, küzdőképes személyiség, a pozitív kimenettel kapcsolatos attitűd, a koherencia érzék, az összefüggések megértésének képessége, valamint az éntudatosság bizonyult. Lazarus (1966, idézi Oláh, 2005, 57. old.) szerint „,megküzdésnek tekinthetö minden olyan kognitív vagy viselkedéses eröfeszités, amellyel az egyén azokat a külsö vagy belsö hatásokat próbálja kezelni, amelyeket úgy értékel, hogy azok felülmúlják vagy felemésztik aktuális személyes forrásait."

A megküzdés egy többlépéses folyamatnak tekinthető, amelynek első lépésében, az elsődleges értékeléskor annak tisztázására kerül sor, hogy az adott helyzetnek mekkora a jelentősége a számunkra, milyen érzelmekkel reagálunk rá (a megküzdés szoros együttjárást mutat az adott érzelmi állapottal). A másodlagos értékeléskor annak vizsgálata történik meg, hogy tudjuk-e kontrollálni az adott helyzetet, rendelkezésünkre állnak-e az ehhez szükséges erőforrások. Ezek alapján dől el, 
milyen megküzdési stratégiát választunk majd. Általában érzelemorientált megküzdéssel (passzivitással, érzelemcsillapítással) reagálunk, ha kívülről irányítottnak értékeljük a helyzetet, ha veszteségként éljük meg, míg problémaorientált megküzdéssel (konstruktivitással) reagálunk, ha kihívásként éljük meg az adott helyzetet vagy megváltoztathatónak értékeljük. Mivel időskorban a problémák jelentős része (pl. halálesetek, nyugdíjba vonulás, egészség romlása) már nem megváltoztatható, így az érzelemorientált megküzdés kerül előtérbe. A megküzdési stratégiák a forráshiányosként megélt helyzetben irányulhatnak a meglévő források bővítésére (információgyüjtés), a hiányzó források megteremtésére (kreativitás, problémamegoldás), a források mobilizálására (támaszkeresés, segítségkérés) vagy a forrásfelhasználás korlátozására (visszahúzódás, relaxáció) (Oláh, 2005).

Időben a megküzdés irányulhat múltbeli (reaktív megküzdés) vagy jövőbeli eseményekre (preventív, anticipált, proaktív megküzdés). A reaktív megküzdés egy múltbeli esemény hatásának kompenzálására, a veszteségek mérséklésére és elfogadására vonatkozik. Preventív megküzdés esetén az esemény még nem következett be, bekövetkezése bizonytalan és időben távoli, cél az erőforrásgyüjtés (pl. kompetenciák fejlesztése) és a kockázatok felmérése. Az anticipált megküzdés esetén az esemény, amellyel majd meg kell küzdeni, a közeli jövőben várhatóan bekövetkezik, cél a konkrét lépések megtétele és az énhatékonyság érzésének (események befolyásolásának képessége) növelése. A proaktív megküzdés során az illető erőforrásait a konstruktív megoldások kialakítására fordítja, veszteség helyett inkább kihívásként tekint a jövőbeli eseményre, élete jobbítására, fejlödésére törekszik (Schwarzer és Taubert, 2002).

\section{Az élet értelme}

Az élet vége felé közeledve óhatatlanul felmerül, hogy van-e valami, amit hátra hagyhatunk a világban, sikerült-e életünk értelmét beteljesíteni? Amennyiben nem sikerül életünk értelmét beteljesíteni, az értelmetlenség érzése uralkodhat el rajtunk.

Frankl (2012, 89. old.) szerint az élet értelme maga az élet, s ez nem merül ki pusztán a létböl, a létet, mint feladatot is jelenti. „Nem csupán arról van szó, hogy ember legyek, hanem arról is, hogy önmagammá legyek.” Az élet értelme abban rejlik, hogy az ember saját lényegét hívja életre, így a létezés értelme mindig csak konkrét lehet, hiszen minden személynek és minden személyes helyzetnek is saját értelembeteljesítés felel meg. Az ember tehát nem pusztán létezik, hanem minden helyzetben dönt arról, hogy ki és mi ő. Ez a döntés szabadsága, a döntésért való felelősség felvállalása, létünk felelősségteljes vállalása, az emberi egzisztencia egyszeriségével és egyediségével szembeni 
felelősség. Ezen kívül létezik egy végső, átfogó értelem is, az életnek, mint egésznek az értelme (Frankl, 2002; 2006; 2012; 2015).

$\mathrm{Az}$ emberi lét tehát értelemre irányuló lét. Értelmet nem lehet adni, azt meg kell találni, mindenkinek önmagának. Az élet értelmét nem lehet kitalálni, létrehozni, azt fel kell fedezni, megtalálni. Az értelemtalálás nem más, mint hogy az ember a saját életének a maga egyediségében és egyszeriségében értelmet kölcsönözzön. Az értelem beteljesítése által ugyanakkor megvalósíthatja önmagát (Frankl, 2002; 2006; 2015).

Az ember háromféle módon tud értelmet találni. Az alkotó értékek valaminek az aktív létrehozását jelentik, ilyen lehet egy hivatás gyakorlása, vagy művészi alkotás létrehozása is. Az élményértékek nem teremtésre, inkább befogadásra, átélésre, szeretetre vonatkoznak, amelyet a természet csodálata vagy egy műalkotás esztétikai értékének élvezete által valósítunk meg. A beállitódási értékek azt fejezik ki, milyen az ember beállítódása létének korlátozásaival szemben, a megmásíthatatlan dolgokhoz való hozzáállása, mint amilyen a szenvedés, halál méltósággal viselése. A három értékkategória hierarchiája alapján a beállítódási értékek a másik két kategória felett állnak (Frankl, 1996; 2002; 2015).

Az élet vége felé közeledve óhatatlanul felmerül, hogy van-e valami, amit hátra hagyhatunk a világban, sikerült-e életünk értelmét beteljesíteni? „Éppen az élet végső határának a ténye, tehát a cselekvési lehetösége az, amely rákényszerít az idő kihasználására, arra, hogy a cselekvési lehetöségeket ne hagyjuk tétlenül elmúlni. Tehát éppen a halál kölcsönöz egyszeri életünknek és létezésünknek értelmet." (Frankl, 2006, 16. old.).

Amennyiben nem sikerül életünk értelmét beteljesíteni, az értelmetlenség érzése uralkodhat el rajtunk, s ez az „egzisztenciális vákuum” unalom és közömbösség formájában nyilvánul meg. Kedvező esetben azonban ez a hiányérzet a fejlődés lehetőségét hordozza magában és értelemkeresésben nyilvánul meg. Az élet értelmének keresése tehát kettős természetü, hiszen magában hordozza az elbizonytalanodás és a fejlődés lehetőségét is (Frankl, 1996; 2002).

$\mathrm{Az}$ értelem magasabb megélése a személyiség szintjén magasabb extroverzióval, nyitottsággal, barátságossággal és alacsonyabb érzelmi labilitással, valamint a jólléttel és az intrinzik életcélok (fejlődés és kapcsolatok) fontosságával függ össze, így az élet értelmesként való megélése a lelki egészség jelzője. Az értelem keresése ennél összetettebb, mivel egyrészt gyenge pozitív kapcsolatot mutat az említett jegyekkel az érzelmi labilitást kivéve, mert azzal erős pozitív kapcsolat mutatható ki. Az értelem keresése így egyszerre tartalmazza a lelki feszültséget, bizonytalanságot és a nyitottságot, a fejlődés lehetőségét, a kapcsolatok és közösségi elkötelezettség keresésének fontosságát is, egyfajta védőfaktornak tekinthető. A megélés és keresés együttes hiánya ugyanakkor alacsony nyitottsággal, a személyiség beszükülésével járhat (Martos és Konkoly Thege, 2012). 
Az idősödő és időskorú emberek számára megfontolandó, hogy fogyatkozó idejüket, anyagi és testi erőforrásaikat milyen célok elérésére fordítsák. Egyre több idő jut a szabadidős tevékenységek végzésére, az időskorba lépve ismét életük részét képezhetik olyan dolgok, melyekre életük korábbi szakaszaiban nem jutott idő (pl. hobbik, kreatív tevékenységek, müvészetek).

Az alkotás folyamata önkifejezés, lehetőséget teremt a belső tartalmak kivetítésére. Az alkotó müvészeket személyiségtesztek és kérdőíves vizsgálatok alapján túlérzékenység, impulzivitás, önérvényesítés, kreativitás, divergens gondolkodás, verbális gazdagság jellemzi (Csíkszentmihályi, 2014; Halász, 2006). A tevékeny, alkotó folyamat lehetőséget teremt az időskorban nehezen feldolgozható gondolatok, belső tartalmak (pl. elmúlás, magány, halál) feldolgozására. Az alkotó tevékenység, az időről-időre megrendezésre kerülő kiállítások hozzásegíthetik az idős embereket az elismeréshez, a sikerélmény átéléséhez. Mindez végső soron lehetőséget ad az énintegritás fejlődésére és az emberi élet utolsó szakaszának örömteli befejezéséhez, a beteljesedés érzéséhez.

Ezen szempontok áttekintése is alátámasztja, hogy érdemes és szükséges foglalkozni az idős emberek helyzetével és már az időskorba való átmenettel is. Kutatásunkban azt vizsgáltuk, hogy életük utolsó szakaszát, szakaszait hogyan élik meg azok az idősödő és időskorú emberek, akik életük ezen szakaszában alkotó tevékenységgel foglalkoznak. Alkotó tevékenység alatt valamilyen maradandó alkotás létrehozására irányuló tevékenységet értünk, amely elsősorban a képzőművészeti (pl. grafika, festészet, szobrászat, fényképezés) és textilmüvészeti tevékenység (pl. szövés, hímzés, csipkekészítés), továbbá kézmüvesség (pl. fa-, fémmegmunkálás, korongozás, varrás, kötés). Az élet utolsó szakaszának, s ezáltal az egész élet lezárásának megítélésére az időskori depressziót, az élettel való elégedettséget, az élet értelmességének megítélését és a megküzdést használtuk.

Kutatásunkban szintén vizsgáltuk a különféle élethelyzetekben (például egyedüllét, családdal vagy barátokkal töltött idő, háztartási munkavégzés vagy szabadidős tevékenység alatt) átélt áramlatélményt, melynek eredményei egy másik tanulmány keretében kerülnek bemutatásra (Aktív, alkotó idősödés II. - Áramlat-élmény).

\section{MÓDSZEREK ÉS MINTA}

Vizsgálatunkat 2017 tavaszán végeztük, a kutatás etikai engedélyét a Debreceni Egyetem 2017/46/91. számon adta meg. A vizsgálati személyek idősödő és időskorú személyek voltak, toborzásuk részben informális kapcsolati hálón keresztül, részben alkotómühelyek, klubok megkeresésével történt. A speciális korcsoport vizsgálata internetes kérdőív helyett nyomtatott 
önkitöltős kérdőív használatát tette szükségessé, mivel ezen korosztály jelentős része nem használ napi szinten számítógépet. Az alkotó tevékenységet végzők az előzetes megkeresésre támogatóan reagáló klubokban alkotók (Budapest XI. kerület Újbuda 60+ programsorozatának festőcsoportjai, a Budapesti Müvelődési Központ Alkotó Stúdiói, a Budakeszi Generációk Háza Alkotó Körei), továbbá egyéb klubokban vagy önállóan alkotók közül kerületek ki.

A mintavétel során a nemek közötti egyenletes megoszlás nem volt biztosítható, mivel az alkotóműhelyekben, alkotóklubokban müködő alkotó csoportok résztvevői döntő többségben nők voltak. Arra azonban törekedtünk, hogy a kontrollcsoportban is az alkotók csoportjához hasonló legyen a nemek megoszlása. A vizsgálatban 73 fő vett részt, ebből 16 férfi $(21,9 \%)$ és 57 nő (78,1 \%). A résztvevők életkora 60-91 év, átlagosan 70,0 év (median=69,0) volt. Családi állapotukat tekintve 5 fő egyedülálló (6,8 \%), 16 fő elvált (21,9\%), 31 fő házas (42,5\%) és 21 fö özvegy (28,8 \%). Az alkotók csoportjába 37 fő (50,7 \%) került besorolásra, míg a kontrollcsoportba 36 fő (49,3 $\%)$.

A vizsgálat során saját szerkesztésü kérdőivet (alapvető demográfiai adatok és az alkotó vagy egyéb szabadidős tevékenység végzésére irányuló kérdések), továbbá az alábbi standardizált kérdőíveket használtuk.

Idöskori Depresszió Skála - röviditett változat (Geriatric Depression Scale, GDS, Brink, Yesavage, 1982)

Az időskori depresszió kiszürésére használatos tesz, melynek eredeti változata 31, rövidített változata 15, a napi életmódra és érzésekre vonatkozó kérdést tartalmaz. A rövidített változatban minden válasz 1 pontot ér a 2., 3., 4., 6., 8., 9., 10., 12., 14., 15. kérdésre „,igen”, míg az 1., 5., 7., 11., 13. kérdésre „nem” válasz esetén. Értékelés: normál (0-4 pont), enyhe depresszió (5-8 pont), mérsékelt depresszió (9-11 pont), súlyos depresszió (12-15 pont).

Élettel való Elégedettség Skála (Satisfaction With Life Scale, SWLS, Diener, Emmons, Larsen és Griffin, 1985)

Az élettel való elégedettség egy adott személy életminőségének szubjektív kognitív értékelése, a pozitív életminőség, a lelki egészség, szubjektív jóllét egyik összetevője. A szubjektív jóllét feltárását célozó teszt egy 5 kérdésből álló kérdőív, a kérdésekkel való egyetértés 7 fokozatú Likert-skálán fejezhető ki. A pontszámok összegzése által kapott érték fejezi ki az elégedettséget. Értékelés: rendkívül elégedett (31-35), elégedett (26-30), enyhén elégedett (21-25), neutrális (20), enyhén elégedetlen (15-19), elégedetlen (10-14), rendkívül elégedetlen (5-9). 
Élet Értelme Kérdőiv (Meaning in Life Questionnaire, MLQ, Steger és mts., 2006)

Az élet értelmének megélését és keresését mérő kérdőív 10 kérdésből áll, az állításokkal való egyetértést 7 fokozatú Likert-skálán kell jelölni. Az 1, 4, 5, 6, 9 kérdések vonatkoznak az élet értelmének megélésére, míg a 2, 3, 7, 8, 10 kérdések az élet értelmének keresésére. Az értelmesség keresése nem az értelmesség megélésének hiánya, hanem önálló dimenzió, a két alskála (megélés és keresés) elkülönül egymástól.

\section{Proaktív Megküzdés Kérdöív (Proactive Coping Inventory, PCI, Greenglass ER., 2002)}

A kérdőív 55 kérdésből áll, a kérdésekkel való egyetértés 4 fokozatú Likert-skálán fejezhető ki, a kérdéseket az alábbi hét alskálába lehet besorolni, amely alskálák szorosan kapcsolódnak a megküzdés pozitív dimenzióihoz.

A proaktív megküzdés az egyéni erőforrások mozgósításának képességét jelenti szubjektív kihívást jelentő helyzetekre nézve, önszabályozáson alapuló folyamatokat foglal magában, a személyes fejlődés, a célok elérése készteti cselekvésre a személyt. A reflektív megküzdés a probléma több lehetséges megoldási alternatívájának szimulációját, a megoldáshoz szükséges erőforrások feltárását és elemzését jelenti. A stratégiai tervezés a komplexebb feladatok kezelhető egységekre történő bontásának célorientált viselkedését jelenti. A preventív megküzdés a jövő egy bizonytalan és szubjektív fenyegető eseményére való előzetes felkészülés képessége. Az instrumentális támaszkeresés arra utal, hogy a személy mennyiben támaszkodik a szociális hálóját alkotó emberek tanácsaira, visszajelzéseire. Az érzelmi támaszkeresés arra utal, hogy a személy hogyan képes hatékonyan azonosítani környezetében azokat a személyeket, akik segítségére tudnak lenni az érzelmi eredetủ problémákkal való megküzdésben. Az elkerülő megküzdés pedig a probléma megoldásának halogatását jelenti (Greenglass, 2002).

Vizsgálatunkban a következő hipotéziseket fogalmaztuk meg. H1: Az alkotó tevékenységet végzők a kontrollcsoporthoz képest kevésbé depressziósak, elégedettebbek az életükkel és értelmesebbnek ítélik meg életüket. $H 2$ : Az alkotó tevékenységet végzőkre eltérő megküzdési módok jellemzők, mint a kontrollcsoportra.

A felvett kérdőívek eredményeit Microsoft Excel és RStudio matematikai-statisztikai programmal elemeztük. Valamennyi folytonos változóra (depresszió, életelégedettség, életértelem alskálák, megküzdés alskálák) kapott pontszámok, továbbá értékek esetében normalitás vizsgálatot végeztünk a Shapiro-Wilk teszttel (p>0.05 esetén a változó normál eloszlású). A normális eloszlású változók esetében az egyes csoportok összehasonlítását kétmintás t-próbával végeztük el és átlag 
értékek kerültek megadásra, míg a nem normális eloszlású változók esetében a Mann-Whitney próbát alkalmaztuk és a medián értékek kerültek megadásra. Az egyes csoportokon belüli összehasonlításokat Friedman-próbával, majd páros Wilcoxon-próbával végeztük el.

\section{EREDMÉNYEK}

Az alkotók csoportjába tartozók főként festészettel, grafikával és kézműves alkotó tevékenységgel foglalkoznak rendszeresen, heti 1-20 órában (átlagosan 7,4 órában), legalább 1/2 éve (átlagosan 21,5 éve). Többségük (22 fö) csoportban (alkotóházban, klubokban) és otthon egyedül is végez alkotó tevékenységet, míg 11 fő csak egyedül, 6 fő pedig kizárólag csoportban. 60 \% (22 fő) élete korábbi szakaszában is foglalkozott már alkotó tevékenységgel, míg $11 \%$-uk (4 fö) esetében az alkotó tevékenység kezdete a nyugdíjba vonuláshoz köthető. A kontrollcsoportba tartozók 36 \%-a (13 fö) nem jelölt meg olyan szabadidős tevékenységet, amellyel rendszeresen foglalkozna. $64 \%$-uk (23 fö) főként passzív tevékenységeket (olvasás, rejtvényfejtés, írás), testmozgással járó tevékenységeket (torna, kertészkedés), illetve kulturális eseményeken való részvételt (színház, klubok) jelölt meg szabadidős tevékenységként. Heti 2-20 órában (átlagosan 8,6 órában), legalább 1/2 éve (átlagosan 24,1 éve) foglalkoznak ezen tevékenységekkel, többségük (10 fö) otthon egyedül, 2 fö kizárólag csoportban, míg 8 fő csoportban és egyedül is. $65 \%$ (15 fö) élete korábbi szakaszában is foglalkozott már a megjelölt tevékenységgel, míg $26 \%$ (6 fö) esetében a megjelölt szabadidős tevékenység kezdete a nyugdíjba vonuláshoz köthető.

\section{Időskori depresszió}

Az Időskori Depresszió Skálán (GDS) elért eredmények alapján a két csoport között nincs szignifikáns eltérés ( $\mathrm{p}=0.4181)$, mindkét csoport mediánja, továbbá mindkét csoport többsége (75-80 $\%)$ is a normál tartományba tartozik. Ez némiképp kedvezőbb helyzetet tár fel a szakirodalmi adatokhoz képest, amelyek szerint a 65 feletti korosztályt inkább az enyhe fokú depresszió (GDS > 4,00) jellemzi (Kopp és Kovács, 2006).

\begin{tabular}{|l|c|c|c|c|c|}
\hline Csoport & $\begin{array}{c}\text { GDS } \\
\text { median }\end{array}$ & $\begin{array}{c}\text { súlyos } \\
\text { depresszió }\end{array}$ & $\begin{array}{c}\text { mérsékelt } \\
\text { depresszió }\end{array}$ & $\begin{array}{c}\text { enyhe } \\
\text { depresszió }\end{array}$ & normál \\
\hline Alkotók & 2,00 & $2,7 \%$ & $2,7 \%$ & $18,9 \%$ & $75,7 \%$ \\
\hline Kontroll & 3,00 & & $5,5 \%$ & $13,9 \%$ & $80,5 \%$ \\
\hline
\end{tabular}

1. táblázat: Időskori depresszió a csoportokban 


\section{Élettel való elégedettség}

Az Életelégedettség Skálán (SWLS) elért eredmények alapján a két csoport között nincs szignifikáns eltérés $(\mathrm{p}=0.6005)$, mindkét csoport átlaga az enyhén elégedett tartományba tartozik, hasonlóan a korábbi hazai adatfelvételek eredményeihez, amelyekben az életelégedettség átlaga 22,68-25,33 közötti, az idősebb életkori csoportokban alacsonyabb az élettel való elégedettség (Martos, Désfalvi, Ittzés, Sallay és Szabó, 2014). Mindkét csoport többsége (70-78 \%) is inkább elégedett, mint elégedetlen.

\begin{tabular}{|l|c|c|c|c|c|c|c|}
\hline Csoport & $\begin{array}{c}\text { SWLS } \\
\text { átlag }\end{array}$ & $\begin{array}{c}\text { elégedet- } \\
\text { len }\end{array}$ & $\begin{array}{c}\text { enyhén } \\
\text { elégedet- } \\
\text { len }\end{array}$ & neutrális & $\begin{array}{c}\text { enyhén } \\
\text { elégedett }\end{array}$ & elégedett & $\begin{array}{c}\text { rendkívül } \\
\text { elégedett }\end{array}$ \\
\hline Alkotók & 24,11 & $10,8 \%$ & $10,8 \%$ & & $40,6 \%$ & $27,0 \%$ & $10,8 \%$ \\
\hline Kontroll & 23,44 & & $13,8 \%$ & $16,7 \%$ & $38,9 \%$ & $27,8 \%$ & $2,8 \%$ \\
\hline
\end{tabular}

2. táblázat: Élettel való elégedettség a csoportokban

\section{Élet értelme}

Az Élet Értelme Kérdőív értelem megélése alskálán elért eredmények alapján a két csoport között nincs szignifikáns eltérés $(\mathrm{p}=0.7684)$, míg az értelem keresése alskála vonatkozásában szignifikáns eltérés mutatkozott $(\mathrm{p}=0.0217)$, az alkotók inkább értelemkeresők, mint a kontrollcsoport tagjai.

A kérdőív magyar adaptációja során (Martos és Konkoly Thege, 2012) az értelem megélésének átlagpontszáma a 45 év felettieknél 26,80 volt, amelytől mind az alkotóknál, mind pedig a kontrollcsoportban jelen vizsgálatban mért értékek kissé elmaradnak. Az értelem keresésének átlagpontszáma a 45 év felettieknél 21,37 volt, amelynél jelen vizsgálatban a kontrollcsoportban mért érték kissé, míg az alkotóknál mért érték jelentősebben magasabb lett. Mindez nem erősíti meg azt az elképzelést, mely szerint az értelem megélése az idősebb korosztályban magasabb, míg az értelem keresése alacsonyabb lenne.

\begin{tabular}{|l|c|c|}
\hline \multicolumn{1}{|c|}{ Csoport } & $\begin{array}{c}\text { értelem megélése } \\
\text { median }\end{array}$ & $\begin{array}{c}\text { értelem keresése } \\
\text { median }\end{array}$ \\
\hline Alkotók & 25,0 & 27,0 \\
\hline Kontroll & 24,5 & 23,0 \\
\hline
\end{tabular}

3. táblázat: Élet értelmessége a csoportokban 
Az Proaktív Megküzdés Kérdőív értékelése során 2 kérdést nem vettünk számításba, mivel ezen kérdések kevésbé értelmezhetők a vizsgált korcsoport tekintetében, továbbá számos esetben nem is kerültek kitöltésre: „Ha megpályázok egy állást, elképzelem magam, ahogy betöltöm azt” (proaktív megküzdés alskála) és „Szakmailag képzem magam, hogy elkerüljem a munkanélküliséget” (preventív megküzdés). A kérdőív validálása során megállapításra került, hogy alskálánként 1-1 tétel elhagyható (Greenlass, 2002).

A kérdőív egyes alskáláin elért eredmények alapján a két csoport között egyetlen alskálán sincs szignifikáns eltérés. Az egyes megküzdési módok között azonban szignifikáns eltérés van mind az alkotók csoportjában (Friedman chi-sq=56.344, p=2.48e-10), mind pedig a kontrollcsoportban (Friedman chi-sq=39.075, p=6.919e-07).

Az alkotók csoportján belül a reflektív megküzdés magasabb értéket mutat a többi megküzdési módhoz képest (az elkerülő megküzdéssel összevetve: $p=0.0007496$ ), illetve az elkerülő megküzdés szignifikánsan alacsonyabb értéket mutat valamennyi megküzdéshez képest. A reflektív megküzdés az alkotók kreativitásából és divergens gondolkodásából is adódhat (Csíkszentmihályi, 2014; Halász, 2006). A kontrollcsoportban ugyanakkor az instrumentális támaszkeresés mutat magasabb értéket a többi megküzdési módhoz képest, míg az elkerülő megküzdés ebben a csoportban is szignifikánsan alacsonyabb értéket mutat valamennyi megküzdéshez képest (az instrumentális támaszkereséssel összevetve: $p=0.004779)$.

\begin{tabular}{|l|c|c|}
\hline Proaktív Megküzdés Kérdőív alskálái & $\begin{array}{c}\text { Alkotók } \\
\text { median }\end{array}$ & $\begin{array}{c}\text { Kontroll } \\
\text { median }\end{array}$ \\
\hline proaktív megküzdés & 3,150 & 3,150 \\
\hline reflektív megküzdés & 3,270 & 3,225 \\
\hline stratégiai tervezés & 3,000 & 3,000 \\
\hline preventív megküzdés & 3,110 & 3,110 \\
\hline instrumentális támaszkeresés & 3,130 & 3,250 \\
\hline érzelmi támaszkeresés & 3,000 & 3,000 \\
\hline elkerülő megküzdés & 2,250 & 2,500 \\
\hline
\end{tabular}

4. táblázat: Proaktív megküzdés alskálái a csoportokban 


\section{KÖVETKEZTETÉSEK ÉS JAVASLATOK}

Kutatásunkban azt vizsgáltuk, hogy életük utolsó szakaszát hogyan élik meg azok az idősödő és időskorú emberek, akik képzőmüvészeti, textilművészeti és kézműves alkotó tevékenységgel foglalkoznak.

Feltételezésünk szerint összefüggés van az alkotó tevékenység és a depresszió, az élettel való életelégedettség és az életértelem között, az alkotók a kontrollcsoporthoz képest kevésbé depressziósak, elégedettebbek az életükkel és értelmesebbnek itélik meg életüket. Feltételezésünket csak részben sikerült alátámasztani, mivel az alkotók és a kontrollcsoport között nincs szignifikáns különbség depresszió, élettel való elégedettség és az élet értelmének megélése tekintetében. Az alkotók egyedül az élet értelmének keresése tekintetében tértek el a kontrollcsoporttól. Mivel az értelem keresése egyaránt tartalmazza a lelki feszültséget, bizonytalanságot és a nyitottságot, a fejlődés lehetőségét, a kapcsolatok és közösségi elkötelezettség keresésének fontosságát is, így egyfajta védőfaktornak tekinthető. Az értelem keresésének alkotóknál mért magasabb szintje összefüggésben lehet a keresés ezen összetett jellegével, mely magában hordozhatja az életszakaszváltással együtt járó lelki feszültséget és az azzal való megküzdés és a fejlődés lehetőségét is, így az alkotó tevékenység etekintetben is védőfaktorként értelmezhető.

Feltételezésünk szerint az alkotó tevékenységet végzőkre eltérő megküzdési módok jellemzők, mint a kontrollcsoportra. Feltételezésünket csak részben sikerült alátámasztani. Bár a proaktív megküzdés egyetlen alskáláján sincs szignifikáns eltérés a két csoport között, az alkotók csoportjában ugyanakkor a reflektív megküzdés mutatta a legmagasabb értéket a többi megküzdéshez képest, míg a kontrollcsoportban az instrumentális támaszkeresés. Mivel a reflektív megküzdés egy adott problémára adható többféle megoldási lehetőség és a megoldáshoz szükséges erőforrások feltárását és elemzését jelenti, így az alkotó tevékenységet folytatók esetében ezen megküzdési mód preferálása az alkotók kreativitásából és divergens gondolkodásából is adódhat.

Mivel jelen vizsgálat során több ponton is a szakirodalomban talált adatokhoz nem illeszkedő eredményt kaptunk, így egy következő vizsgálatban érdemes lenne alaposabban megvizsgálni ezen anomáliákat. Az alkotó tevékenységet végzök magas értelemkeresésének indokát interjúkkal lehetne alátámasztani, illetve érdemes lenne kiterjeszteni különböző korosztályokra, illetve az alkotó tevékenységen kívüli egyéb, aktivitással vagy tanulással járó tevékenységekre is. Ezek a vizsgálatok választ adhatnak arra, hogy az idősebb korosztályban alkotó tevékenységgel foglalkozók magas értelemkeresése inkább az alkotó tevékenységnek vagy inkább az életkornak tudható be, esetleg ezek együttes hatásának. 


\section{IRODALOMJEGYZÉK}

Bácskay A., Balogh K., Gregorits P., Kovács B., Mura-Mészáros P., Németh M., Pintér Á., Szabó R. (szerk.): Szociális statisztikai évkönyv, 2016. KSH, 2017

Balaskó M., Pétervári E., Székely A. (2013): Az idősödő szervezet: táplálkozás, mozgás és fiziológiai változások. In: Kállai J., Kaszás B, Tiringer I. (szerk.): Az időskorúak egészségpszichológiája. Medicina Kiadó, Budapest. 151-178.

Brandtstadter J. (2011): Adaptív erőforrások az élet második felében. In: Csíkszentmihályi M., Csikszentmihalyi I. S. (szerk.): Élni jó! Tanulmányok a pozitív pszichológiáról. Akadémiai Kiadó, Budapest. 187-214.

Brink TL, Yesavage J. A et al. Screening test for geriatric depression. Clin Gerontologist J : 37-44, 1982. In: 75 papir-ceruza tesz. Animula Kiadó, Budapest

Csíkszentmihályi M. (2014): Kreativitás. A flow és a felfedezés, avagy a találékonyság pszichológiája. Akadémiai Kiadó, Budapest.

Diener, E. (1985) The Satisfaction Whith Life Scale, J Person Assessm, 49. I. In: 75 papir-ceruza tesz. Animula Kiadó, Budapest

Frankl, V. E. (1996): Az ember az értelemre irányuló kérdéssel szemben. Kötet Kiadó, Budapest.

Frankl, V. E. (2002): A tudattalan Isten. Pszichoterápia és vallás. EuroAdvice Kiadó, Budapest.

Frankl, V. E. (2006): Értelem és egzisztencia. Elöadások és tanilmányok. Jel Kiadó, Budapest.

Frankl, V. E. (2012): A szenvedö ember. Patodicea-kísérlet. Jel Kiadó, Budapest.

Frankl, V. E. (2015): Orvosi lelkigondozás. A logoterápia és egzisztenciaanalízis alapjai. Jel Kiadó, Budapest.

Füzesi Zs., Törőcsik M., Lampek K. (2013): Az időskor egészségszociológiája: tények és trendek. In:

Kállai J., Kaszás B, Tiringer I. (szerk.): Az időskorúak egészségpszichológiája. Medicina Kiadó, Budapest. 63-83.

Greenglass, E. R. (2002): Proactive coping and quality of life management. In E Frydenberg (Ed.), Beyond coping: Meeting goals, visions, and challanges. (pp. 37-62). London: Oxford University Press.

Hajduska M. (2015): Krízislélektan. ELTE Eötvös Kiadó, Budapest.

Halász L. (2006): Müvészetpszichológia. In: Bagdy E., Klein S. (szerk.): Alkalmazott pszichológia. Edge 2000 Kiadó, Budapest. 187-203.

Kopp M., Kovács M. E. (szerk.) (2006): A magyar népesség életminösége az ezredfordulón. Semmelweis Egyetem Magatartástudományi Intézete. Semmelweis Kiadó, Budapest. 
Kopp M., Székely A. (2013): Nagyszülők, szülők és unokák: testi és lelki egészség. A generációk közötti kapcsolatok egészségpszichológiai szerepe. In: Kállai J., Kaszás B, Tiringer I. (szerk.): Az időskorúak egészségpszichológiája. Medicina Kiadó, Budapest. 105-118.

Lazarus, R. S. (1966): Psychological stress and coping process. New York: McGraw-Hill.

Martos T., Konkoly Thege B. (2012): Aki keres és aki talál - az élet értelmessége keresésének és megélésének mérése az Élet Értelme Kérdőív magyar változatával. Magyar Pszichológiai Szemle, 2012, 67. 1. 125-149.

Martos T., Désfalvi J., Ittzés A., Sallay V., Szabó T. (2014): Az Élettel való Elégedettség Skála magyar változatának (SWLS-H) pszichometriai jellemzői. Mentálhigiéné és Pszichoszomatika 15 (2014) 3, 289-303.

Monostori J., Gresits G. (2018): Idősödés. In: Demográfiai portré 2018. Jelentés a magyar népesség helyzetéről. KSH Népességtudományi Kutatóintézet. 127-145.

Nurmi J-E., Salmela-Aro K. (2011): Ami müködik, az boldoggá is tesz. In: Csíkszentmihályi M., Csikszentmihalyi I. S. (szerk.): Élni jó! Tanulmányok a pozitív pszichológiáról. Akadémiai Kiadó, Budapest. 236-258.

Oláh A. (2005.): Érzelmek, megküzdés és optimális élmény. Trefort Kiadó, Budapest

Schwarzer, R., \& Taubert, S. (2002): Tenacious goal pursuits and striving toward personal growth: Proactive coping. In E. Frydenberg (szerk.): Beyond coping: Meeting goals, visions and challenges (pp. 19-35). London: Oxford University Press.

Steger, M. F., Frazier, P., Oishi, S., Kaler, M. (2006): The Meaning in Life Questionnaire: Assessing the Presence of the Search for Meaning in Life. Journal of Counseling Psychology, 53, 80-93.

World Population Ageing (2013): United Nations. New York, 2013. In: Lampek K., Rétsági E. (2015): Egészséges idősödés - az egészségfejlesztés lehetőségei időskorban. Pécsi Tudományegyetem Egészségtudományi Kar 